DOI: 10.20472/IAC.2019.052.059

\author{
ABIGAIL STIGLINGH \\ NORTH-WEST UNIVERSITY, South Africa \\ LERATO MOTHIBI \\ NORTH-WEST UNIVERSITY, South Africa
}

\title{
THE LINK BETWEEN GOVERNMENT EXPENDITURE AND DEBT AS POTENTIAL DRIVERS OF ECONOMIC GROWTH IN SOUTH AFRICA
}

\begin{abstract}
:
The financial burden of public debt in the lives of South Africans has undergone considerable change and continues to evolve since the beginning of democracy in 1994. Many countries, specifically the OCED countries have experienced expanding levels of debt to GDP ratio since the global financial crises in 2008/2009, where South Africa's gross debt ratio averaged $44.8 \%$ in 2017. Making use of the autoregressive distributive lag model (ARDL), the study utilises data from 1980 to 2017 in order to investigate the relationship between government expenditure and debt as potential drivers of economic growth. Furthermore, the study's aim is to identify weather or not government expenditure and debt could be identified as positive or negative contributors towards economic growth in South Africa. The study further seeks to identify the link between government expenditure and debt since, government expenditure in South Africa has diligently surpassed its revenue, where the deficit is in most cases is funded through the accumulation of unsustainable debt. The findings of the study reveal a negative relationship between economic growth and government expenditure. In addition, the study also reveals a positive relationship between economic growth and government debt. This therefore indicates the need for stricter government expenditure and debt management policies, as unsustainable debt levels and unregulated government expenditure could be detrimental for the South African economy.
\end{abstract}

\section{Keywords:}

ARDL model, economic growth, government expenditure, debt.

JEL Classification: D00, C01, A10 


\section{INTRODUCTION}

The concept that increased government spending can stimulate economic growth is a quite controversial issue among researchers and scholars around the world. The amount of liabilities that a government has, including domestic debt and foreign debt, is often described as public or government debt. Many countries, specifically developing countries, have experienced expanding levels of debt-to-GDP ratio since the global financial crises in 2008/2009, where South Africa's gross debt ratio averaged 44.8\% in 2017 (IMF, 2017). Accordingly, Jibao et al. (2013), in their study, indicate that as a result of the financial global crises, public finances have deteriorated significantly, where the lack of recovery from the crisis profoundly affected the tax base. Government expenditure in South Africa has diligently surpassed its revenue, where the deficit, in most cases, is funded through the accumulating and unsustainable public debt. South Africa is not unique to the situation of debt, as during the course of recent decades, government debt has been increasing significantly as this pattern coincided with an expansion in the size of the government. Furthermore, the budget review (2018) indicates that R528.4 billion was allocated to spending on social grants, R324 billion was allocated to spending on higher education, and R35 billion was allocated to infrastructure; however, even though expenditure is on the rise, the South African economy has also weakened, where the country slipped into a technical recession during the first quarter of 2018 (StatsSA, 2018).

The study of Cameron (2004) further asserts that, in the public sector, good governance plays a vital role because investors would rather invest in a country that demonstrates good governance instead of one that does not demonstrate any commitment towards it. Achieving sustainable and inclusive economic growth remains a major challenge for economic policy and for government. Because the global financial crises could not be solved through the implementation of monetary policy, as a result, Mellet (2012) asserts that public debt for both emerging and advanced economies has increased. Mohr and Fourie (2011) assert that fiscal policy should further focus on reducing the debt levels, which therefore indicates a need for policymakers to address the challenge of the soaring government debt and expenditure levels in South Africa, as difficult as it may be.

As of late, the main budget instruments that are consistently and rapidly growing are the public debt service costs, amounting to R202.2 billion for the fiscal year 2019/2020's budget expenditure (Budget Review, 2019). This further contributes to the likelihood of crowding out economic and social spending, which may impede the set development objectives and further lead to restraining future economic growth for the nation. This clear and inseparable link between debt, expenditure and economic growth will constitute a focal point of this paper. This paper therefore seeks to investigate whether or not an increase in government expenditure and government debt will bring about economic growth in South Africa.

\subsection{LITERATURE REVIEW}

Over recent years, there has been a strident increase in South Africa's debt and expenditure ratios. The ability of how the economy is able to sustain its finances has become a vital area of discussion since the commencement of the 2008-2009 global financial crisis. This therefore 
signifies the dire need for a sustainable fiscal adjustment as well as a credible debt structure (Mupunga \& Le Roux, 2016). The literature suggests that the rising rates of debt are the consequence of an unsound fiscal policy and, in addition, the lack of regulating and implementing stricter policies (Kukeli, 2014). The weakness of financial institutions leads to the likelihood of fiscal distress in the form of continued lagging financial policies and elevated vulnerability to external shocks (Acemoglu \& Robinson, 2008; Makin, 2015).

Expenditure also contributes through various channels to economic growth and social development; for example, investments in agricultural and industrial infrastructure create backward and forward connections and lead to employment possibilities. Similarly, health and education investment can lead to greater productivity in the labour force and add to economic growth. The effect of public debt on financial development and most importantly economic growth in developed and less developed nations is characterised by a broad range of literature (Eberhardt \& Presbitero, 2015; Nantwi \& Erickson, 2016; Stylianou, 2014). There is a complex and distinct connection across nations between expenditure, debt and economic growth. Several studies are performed using distinct econometric methods to explore the relationship between expenditure, debt and economic growth.

\subsubsection{Theories of expenditure and debt}

Theories around the incidence of public debt can be highly debated. Classical economists who structured these theories according to this particular school of thought are Adam Smith and David Ricardo. Both share the same thought, that government should keep spending at a minimum and only cater for certain functions (Tsoulfidis, 2007). Goldsmith (1995) asserted that when government continues to borrow it would result in an outflow of resources and impede the social well-being of the society and therefore suggests that government spending should be covered by taxation. However, in some instances, government debt can assist in collecting capital. Ricardo had the view that the detrimental effects of government are not the source of their funding, but the wastefulness in which they create the debt through spending (Anderson \& Tollison, 1986). Consequently, there will be similar effects on consumers through either incurring public debt or taxation (Barro, 1974). In addition, contributions to the latest endogenous growth literature have shed some light on the role of fiscal policy in influencing the rate of economic growth, with government spending directly affecting the tasks of personal manufacturing (Barro, 1990).

The Keynesian model stipulates that high expenditure levels increase tax charges, which contradicts the constructive outcomes of public expenditure by diminishing investment, which is followed by a decrease in utilisation, higher unemployment rates and decreasing the development stride of the economy. However, in a more recent study, Kumudia (2015) found that at moderate levels, public expenditure may expand economic growth rates. Government can utilise the formation of the expenditure for profitable investments that could grow national income and enhance economic growth. In the event that expenditure is coordinated elsewhere, it may result in some difficulties for economic growth and further strain on financial development. For instance, an increase in expenditure would fuel local economic activities and some private investment groups (Ncanywa \& Masoga, 2018), placing the economy under more strain and financial distress. In an acclaimed theory of Keynesian regarding expenditure, it stated that the increasing government expenditure is linked to higher national output, which leads to employment (Makin, 
2015). However, the assets and funding available for investment may have been crowded out by the increased government expenditure; therefore, the aim of availing funding to pertain more economic growth through investments is hindered. However, the speculation to narrow the saving-investment gap, as suggested by the Keynesian framework, is through foreign investment or foreign aid (Mongale, Petersen, Meniago \& Petersen, 2013).

Within the Keynesian macroeconomic structure, the link between economic growth and public expenditure is viewed as inverse. The standard effective demand theory emphasised the beneficial effect of independent public spending on economic growth. Moreover, the theory finds that national income is a predictive factor in the increasing role of government expenditure, as Wagner puts it. Empirical studies, however, do not support the opinion of the Keynesian theory that public expenditure generates national income.

\subsubsection{Classical theories of expenditure and debt}

Economists favoured debt when mercantilists had an effect. As time passed, the role played by the government was limited. This was the opinion of the economist who thought in classical theory that supported the Laissez Faire policy. This strategy regarded the government as the only organisation capable of enforcing law and order. Economists in this theory believed in perfect competition, mobility of factors and full employment. This theory assumes that government expenditure is unproductive. It also says that public debt will impose a burden that is unnecessary to the society. Adam Smith later argued against the mercantilist regime and the Laissez Faire was generated (Alesina \& Tabellini, 2007). This theory also came to the agreement that public debts are unproductive because it brings burden to the community through interest rates.

The theoretical arguments on debt were examined concerning the Classical, Ricardian's, Keynesian perspectives and endogenous development model. The Classicals saw debt as a capital infusion to be utilised for generation venture instead of utilisation by people (Modigliani, 1961). This suggested that government consumption ought not to be financed by methods for obtaining finances and not being able to pay respect to the conditions thereof. Furthermore, the current debt obligation ought to be dealt with immediately and effectively (Masoga, 2018). The concern remained the high credibility of limitations on the monetary policy and the related constraints they may encounter in view of the structure and the size of debt. Therefore, the government is considering acquiring alternatives for taxes, as an option for duties, along these lines enabling expenditure to increase without direct changes in tax rates.

\subsubsection{Modern theories of expenditure and debt}

The social benefits of capital growth have legitimised Ricardo's preference for tax-financed government expenditure other than public debt. According to Churchman (2001), Ricardo claims that there would be severe repercussions within the economy after the moment of war if public debt were to be used to fund government spending during war, for example. This is simply because tax would have to be imposed in order to pay the accumulated debt. As mentioned by Ricardian's equivalence, the result of today's government borrowing is the future rise in taxation above ordinary level (Modgliani, 1961). As a consequence, the effect of public debt on economic growth would be neutralised. 
The following channels, among others, open up the impact that public debt has on financial development: personal savings, investment in government initiatives, the aggregate productivity factor and real interest rates. As Durham (2004) pointed out, public debt determines economic growth through domestic savings and investment. In addition, large quantities of public debt put domestic savings and investment at risk through crowding-out effects and, as a consequence, reduce economic growth. The conflicts concerning these theoretical views have arisen from the Ricardian equivalence theory, which argues that debt does not influence economic growth. The argument is based on the perspective that increased personal savings arising from more tax declines funded by large amounts of borrowed finances will offset the decrease in government savings (Ncanywa \& Masoga, 2018). According to Durham (2004), low debt has a beneficial impact on economic growth; however, if public debt exceeds certain boundaries, it will have an inverse impact on economic growth.

\subsubsection{Empirical literature review}

Making use of European countries between the time periods 1970 to 1997, the study Taghavi (2000) analysed the theory that public debt has adverse consequences on economic growth, investment as well as inflation. The study utilised the hybrid co-integration as well as the vector autoregressive model. The results revealed that, debt has an adverse impact on investment, however the effects of debt on economic growth remain unclear. In addition, it appears that debt is inflationary in the long run, even though its effect on inflation is not evident in the short run.

Making use of 52 African countries, Lopes et al. (2014) investigated the impact of public debt on economic growth and inflation between the time periods 1950 to 2012 . The results of the study revealed that public debt indeed affects inflation. This implies that, increased amounts of public debt lead to elevated inflation. Furthermore, Nastansky et al. (2014) conducted a study to explore the connection between public debt and inflation, making use of quarterly data from Germany for the period between 1991 and 2010. The findings of the study indicate that; public debt levels have a significant impact on consumer prices.

Likewise, government expenditure was observed to have an asymmetric response to economic growth, as Wahab (2004) investigated the economies of the Organazation for Economic Cooperation and Development (OECD) taking into account the time period 1950 to 2000. In fact, government expenditure does not proportionately rise with an accelerated economic growth, but rather falls more proportionately with lower economic growth. Making use of the European Union 15 (EU-15) countries, the study of Arpaia and Turrini (2008) investigated the long and short term effects between government expenditure and the potential output between 1970 and 2003. Their findings reveal that; that theory of a typical long run elasticity between cyclically-adjusted expenditure and the potential outcome can't be rejected. What's more, long run elasticity had diminished considerably throughout the decades and shows to be significantly higher as compared to that of emerging economies, fast-growing nations, and nations with weak control over legislation for regulating government expenditure as well as low indebted countries. 
Lamartine and Zaghini (2011) analysed the viability of the law expanding government activities for 23 industrialised countries in the third and most recent years of sustained economic growth in government expenditure, from 1970 to 2006. This study provided empirical evidence that supported the existence of a long-term positive correlation between public expenditure and GDP development in 23 OECD developed countries. By using a well-established body of studies, the study has contributed to the outcome of a very successful panel assessment method that made use of both time-series and cross-sectional dimension datasets more effectively.

It is not surprising that the findings of these studies have usually been mixed, thereby encouraging further investigation regarding the relationship between debt and expenditure. The use of integration and co-integration analysis has enhanced the accuracy of the latest works, making it possible to distinguish between long-term and short-term dynamics. However, the scope of these studies was generally restricted to single country or comparisons of outcomes resulting from distinct country analyses only (Akitoby et al., 2006; Islam, 2001; Thornton, 1999).

\subsection{METHODOLOGY}

\subsubsection{Data and sample period}

In order to investigate the link between expenditure and debt, the study uses annual data from the time period 1980 to 2017 . This sample period was chosen due to the availability of data, incorporating a period before and after democracy in South Africa. The variables utilised by this study incorporate real economic growth per capita (RGDP), national government expenditure as a percentage of GDP (GEXP), total loan debt of national government: total domestic debt (GD), budget deficit: balance on current account (BD) and inflation consumer prices (CPI). All data utilised in this study was obtained from the SARB.

\subsubsection{Model specification}

The study makes use of the autoregressive distributed lag model (ARDL), which was developed by Pesaran and Shin (1996) and later revised by Pesaran et al. (2001). The study makes use of the ARDL model for numerous reasons. As indicated by Pesaran and Shin (1994), ARDL makes use of a single and reduced form of equations (Johansen \& Juselius, 1990). Furthermore, another benefit of utilising the ADRL model is that variables can either be integrated at I(0), I(1) or jointly at I(0) and I(1), respectively (Habanabakize et al., 2017). The ARDL model presented below will be used to determine the link between public debt, expenditure and growth.

$$
\begin{aligned}
& \Delta L G D P=\alpha_{0}+\sum_{j=1}^{k} \gamma_{1 i} \Delta L G D P_{t-j}+\sum_{j=1}^{k} \gamma_{2 i} \Delta G E X P_{t-j}+\sum_{j=1}^{k} \gamma_{3 i} \Delta L G D_{t-i}+\sum_{j=1}^{k} \gamma_{4 i} \gamma \Delta C P I_{t-j}+ \\
& \sum_{j=1}^{k} \gamma_{5 i} \Delta B D_{t-j}+\phi_{1} G D P_{t-1}+\phi_{2} G E X P_{t-1}+\phi_{3} L G D_{t-1}+\phi_{4} C P I_{t-1}+\phi_{5} B D_{t-1}+\mu_{t}
\end{aligned}
$$

In such a manner that $\triangle L G D P$ denotes real economic growth per capita at a time ., followed by $\triangle G E X P$, which denotes the change in government expenditure at a time ${ }^{t}$, which is followed by the natural logarithm of government debt at a time $t$, which is further denoted by $\triangle L G D$, followed by consumer prices denoted by $\triangle C P I$ at a time ${ }^{t}$, followed by the balance of payments, which is denoted by $\triangle B D$ at a time $t$. The intercept, number of lags and the error term is denoted by $\alpha_{0}$, 
$k$ and ${ }^{t_{t}}$ respectively. Moreover, the short-run dynamics are denoted by $\gamma_{1}-\gamma_{5}$, and the long-run dynamics are denoted by $\phi_{1}-\phi_{5}$ respectively. To determine the presence of cointegration, the study will make use of equation 1 above to formulate the following hypothesis:

- Co-integration null hypothesis ( $\mathrm{H} 0): \phi_{1}=\phi_{2}=0$

- No no-integration alternative hypothesis $(\mathrm{H} 1): \phi_{1} \neq \phi_{2} \neq 0$

The bounds test, also known as the Wald F-test, is used to test the hypothesis indicated above. With the use of the bounds test, a comparison can be made with regard to comparing the fstatistic and critical value obtained from the Pesaran et al. (2001) table. In an instance where the f-statistic value is larger than the upper critical bound value, this would indicate that a cointegrating relationship exists, meaning that there is a long-run association between the variables utilised. Furthermore, when there is no cointegration between the variable used, the F-statistic is lower than the lower bound critical value. This further also implies that there is no long-run relationship between the variables. Moreover, as indicated by Dube and Zhou (2013), in an instance where the estimated f-statistic lies between the upper and lower critical bound values, the results obtained are inconclusive. When the presence of a long-run relationship is evident, the error correction model $(E C M)$ is derived in the following manner:

$$
\begin{aligned}
& \Delta L G D P=\alpha_{0}+\sum_{j=1}^{k} \gamma_{1 i} \Delta L G D P_{t-j}+\sum_{j=1}^{k} \gamma_{2 i} \Delta L G E X P_{t-j}+\sum_{j=1}^{k} \gamma_{3 i} \Delta L G D_{t-i}+\sum_{j=1}^{k} \gamma_{4 i} \Delta C P I_{t-j}+ \\
& \sum_{j=1}^{k} \gamma_{5 i} \Delta B D_{t-j}+\lambda E C T_{t-i}+\mu_{t}
\end{aligned}
$$

From equation 2 above, the error correction term and its coefficient are denoted by $\lambda E C T_{t-j}$ respectively, which measures the speed of adjustment of the variables towards long-run equilibrium. The study will further make use of the Akaike information criterion (AIC) in order to select the optimal number of lags. The study will further conduct diagnostics and stability tests in order to validate the accuracy of the model utilised.

\subsection{RESULTS AND DISCUSSION}

\subsubsection{Correlation analysis}

In order to analyse the strength and association between the variables utilised, the study makes use of the Pearson correlation analysis, where the correlation coefficient indicated by ( $r$ ) measures the statistical relationship between the variables utilised. Table 1 below provides a summary of the findings of the correlation analysis.

Table 1: Pearson's correlation coefficients

\begin{tabular}{|l|l|l|l|l|l|}
\hline & LRGDP & BD & CPI & EXP & LGD \\
\hline LRGDP & 1.00000 & & & & \\
\cline { 2 - 5 }
\end{tabular}




\begin{tabular}{|l|l|l|l|l|l|}
\hline BD & $-0.85508^{*}$ & 1.00000 & & & \\
\hline CPI & $-0.35837^{*}$ & $0.52264^{*}$ & 1.00000 & & \\
\hline EXP & $0.44600^{*}$ & $-0.6672^{*}$ & $-0.38784^{*}$ & 1.00000 & \\
\hline LGD & $0.52789^{*}$ & $-0.7526^{*}$ & $-0.81840^{*}$ & $0.75544^{*}$ & 1.00000 \\
\hline Note: ${ }^{*}$ and ** denote the level of significance at $5 \%$ and $10 \%$, respectively \\
\hline
\end{tabular}

Source: Own table based on results from Eviews 9

The results obtained reveal that, at the $5 \%$ level of significance, there is a statistically significant correlation between all the variables used. The results further indicate a weak association between CPI and LRGDP, followed by a weak association between EXP and CPI. The results further indicate a moderate associate between $\mathrm{CPI}$ and BD, followed by EXP and LRGDP, followed by LGD and LRGDP. A strong association is observed between EXP and BD, followed by LDG and BD, followed by LGD and EXP. The results further also indicate a very strong association between BD and LRGDP and between LGD and CPI.

\subsubsection{ADF unit root testing}

In an effort to ensure the applicability of the ARDL model, each variable is tested for stationarity making use of the ADF and PP unit root test in order to test the order of integration of the variables as well as ensure that no variables are integrated at I(2). Table 2 below provides a summary of the results obtained.

Table 2: Unit root test

\begin{tabular}{|l|l|l|l|l|l|}
\hline \multirow{2}{*}{ Variable } & \multicolumn{2}{l}{ ADF } & \multicolumn{2}{l|}{ PP } & $\begin{array}{l}\text { Order of } \\
\text { integration }\end{array}$ \\
\cline { 2 - 6 } & t-stats & p-value & t-stats & p-value & \\
\hline LGD & -3.015234 & $0.0429^{*}$ & -5.491011 & $1.0000^{*}$ & $\mathrm{I}(0)$ \\
\hline BD & -5.371111 & $0.0001^{*}$ & -3.372975 & $0.0185^{* *}$ & $\mathrm{I}(1)$ \\
\hline LGEXP & -6.819660 & $0.0000^{*}$ & -6.775852 & $0.0000^{*}$ & $\mathrm{I}(1)$ \\
\hline CPI & -5.230215 & $0.0008^{*}$ & -9.432948 & $0.0000^{*}$ & $\mathrm{I}(1)$ \\
\hline LGDP & -4.196551 & $0.0022^{*}$ & -4.255579 & $0.0019^{*}$ & $\mathrm{I}(1)$ \\
\hline
\end{tabular}

Note: ${ }^{*}$ denotes significance at $1 \%,{ }^{* *}$ denotes significance at $5 \%,{ }^{* *}$ denotes significance at $10 \%$

Source: Own table based on results obtained from Eviews 9

The results indicate that LGD is stationary at levels $\mathrm{I}(0)$ and the variables $B D, L G E X P$ and $C P I$ and LGDP are stationary at first difference I(1). Because no variables are integrated at order I(2), the ADRL model can be used to test for co-integration. 


\subsubsection{Bounds testing}

After confirmation from the unit root test that no variables are integrated at I(2), the ARDL bounds test is used to determine whether or not there exists a long-run relationship (co-integration) between the variables utilised. In order to determine the best ARDL model, the study will make use of the Akaike information criterion (AIC) in order to determine the lag length selection making use of Eviews9 software. The best model selected was ARDL model $(1,0,4,0,2)$.

Table 3 below provides a summary of the bounds testing results.

Table 3: Bounds testing for co-integration

\begin{tabular}{|c|c|c|}
\hline Test statistic & Value & \\
\hline F-statistic & 6.725397 & \\
\hline Critical values & & \\
\hline Significance & Lower bound I(0) & Upper bound I(1) \\
\hline $10 \%$ & 2.2 & 3.09 \\
\hline $5 \%$ & 2.56 & 3.49 \\
\hline $2.5 \%$ & 2.88 & 3.87 \\
\hline $1 \%$ & 3.29 & 4.37 \\
\hline
\end{tabular}

Source: Own table based on results obtained from Eviews 9

The results obtained by this study reveal that the estimated F-statistic is 6.725397 , which is above the upper and lower bound critical values at the $5 \%$ level of significance. The results indicate the presence of a long-run relationship between government debt, expenditure and economic growth in South Africa, and therefore the null hypothesis of no long-run relationship is rejected.

\subsubsection{Long-run analysis}

The long run relationship between the variables is presented in equation 3 below.

$$
L G D P=-0.0000 B D-1.674 L G D-0.687 C P I-0.541 L G E X P+48.6363
$$

A negative relationship is observed between the budget deficit and economic growth. The results reveal that, on average, a percentage increase in the budget deficit will on average result in a decline in economic growth. This holds true, as South Africa is characterised by weak economic growth as well as continuously growing fiscal deficits where, according to the budget review (2019), the budget balance for $2016 / 17$ was recorded to be $-3.6 \%$, followed by $-4.0 \%$ in $2017 / 2018$, which was also further followed by a $-4.5 \%$ for the fiscal year $2019 / 2020$. This is 
primarily caused by the deterioration in economic and revenue outlook indicated in the October 2018 Medium-term Budget Statement (MTBS), which caused the growing pressure of stateowned enterprises' (SOEs') bailouts. This indicates that South Africa is spending more money than it actually has, and therefore the increasing debt levels. Similar results were found by Dao and Doan (2014) who observed a negative relationship between budget deficit and economic growth.

A negative relationship is observed between economic growth and government debt. A one percent increase in government debt will result in a 1.68 average decline in economic growth. These findings are in line with the findings of Pegkas (2018), who found similar results showing that there is a negative relationship between economic growth and public debt in the long run. This negative relationship is attributed to the fact that South Africa is characterised by a high levels of corruption, unemployment, inequality and poverty. This clearly indicates that money that is borrowed from institutions such as the IMF is not used in the most efficient and effective manner. However, rather, borrowed money is transferred into non capital forming ventures, which in this case leaves the country in a worse-off position than before. The literature further postulates that government debt has a negative impact on growth through many channels. The acquiring of debt could lead to reduced productivity as consumers now have to pay increased interest rates and taxes, as government tries to repay its loans. Furthermore, as a result of lower tax revenue collection, the South African net loan debt is anticipated to reach 49.9 percent of GDP for the financial year 2018/2019, and further anticipated to increase to R3.47 trillion, which accounts for $55.5 \%$ of GDP (Budget Review, 2019).

A negative relationship is observed between economic growth and inflation. A $1 \%$ increase in inflation will result in a 0.68 average decline in economic growth. These findings are supported by the findings of Mamo (2012), who also found a negative relationship between economic growth and inflation. These findings demonstrate that as inflation increases, this means that the average South African citizen will have less disposable money than before to spend on basic goods and services, as inflation reduces the value of money. This indicates that the poor will become poorer, especially taking into account the high poverty rate of South Africa.

A negative relationship is observed between economic growth and government expenditure. If government expenditure was to increase by $1 \%$, this would on average result in a $0.54 \%$ decline in economic growth. The budget review further indicates that, over the next three years, R75.3 billion will be spent on the reconfiguration of Eskom, which had raised the expenditure ceiling of the year $2019 / 2020$ by R14 billion, followed by R1.3 million for the year 2020/2021 and R732 million for the year 2021/2022 (Budget Review, 2019). This therefore indicates the need for increased spending on basic education, social protection, healthcare and housing in order to help the economy grow. This supports the idea that as the economy grows, employment opportunities will become available, and therefore lessen the dependency of the South African citizens on the government, which will further lead to a decline in government spending. The findings of this study are supported by the findings of Devarajan et al. (1996), who also found a negative relationship between economic growth and expenditure.

\subsubsection{Short-run and ECM results}

Following the analysis of the long-run relationship, the error correction model was used in order to determine the short-run relationship between the variables. Table 4 below provides a summary of the results of the error correction model. 
Table 4: Short-run and error correction

\begin{tabular}{|l|l|l|l|l|}
\hline Variable & Coefficient & Std. error & t-statistic & p-value \\
\hline BOP & -0.000000 & 0.000000 & -0.302977 & 0.7646 \\
\hline $\mathrm{D}(\mathrm{CPI})$ & -0.004641 & 0.001433 & -3.238150 & $0.0036^{* *}$ \\
\hline $\mathrm{D}(\mathrm{CPI}(-1))$ & 0.001515 & 0.001725 & 0.878236 & 0.3889 \\
\hline $\mathrm{D}(\mathrm{CPI}(-2))$ & 0.003409 & 0.001603 & 2.125825 & $0.0445^{* *}$ \\
\hline $\mathrm{D}(\mathrm{CPI}(-3))$ & 0.001709 & 0.001317 & 1.297547 & 0.2073 \\
\hline $\mathrm{EXP}$ & 0.000029 & 0.000253 & 0.114915 & 0.9095 \\
\hline $\mathrm{D}(\mathrm{LGD})$ & -0.122665 & 0.074780 & -1.640357 & $0.1145^{*}$ \\
\hline $\mathrm{D}(\mathrm{LGD}(-1))$ & 0.255520 & 0.089720 & 2.847978 & $0.0091^{* *}$ \\
\hline CointEq(-1) & -0.009748 & 0.002016 & -4.834249 & 0.0001 \\
\hline \multicolumn{7}{|l|}{ Note: ** denotes significance at 5\% level, * denotes significance at 10\% } \\
\hline
\end{tabular}

Source: Own table based on results obtained from Eviews 9

The results reveal a negative and significant relationship between economic growth and inflation as well as economic growth and government debt. The findings suggest the significance of stable inflation as elevated amounts of inflation are set to be an adverse factor for a country's economic growth, especially the growth of developing countries (Nguyen, 2015). Furthermore, the results further indicate the importance of a stable and low inflation as this is one of macroeconomic objectives of government. The results further assert the fact that most developing countries such as South Africa are subject to borrow in order to deal with the rising fiscal deficits in order to promote economic growth. This therefore leads to elevated debt levels, which at highly unsustainable levels, could be detrimental for the growth of a country. Furthermore, the error correction term indicated by CoinEq(-1) is negative and statistically significant at the $5 \%$ level of significance with a coefficient of -0.009748 and a probability value of 0.0001 . This therefore means that $0.9 \%$ of shocks within the system will be fixed each year. This therefore suggests that inflation and debt reduce economic growth in the short run.

\subsection{DIAGNOSTICS AND STABILITY TEST}

Table 5 below provides a summary of the results obtained from the diagnostics and stability tests.

Table 5: Diagnostics test results

\begin{tabular}{|l|l|l|l|}
\hline $\begin{array}{l}\text { Diagnostics/stability } \\
\text { test }\end{array}$ & Null hypothesis (H0) & P-values & Conclusion \\
\hline $\begin{array}{l}\text { Breusch-Pegan } \\
\text { Godfre } \\
\text { heteroscedasticity }\end{array}$ & No heteroscedasticity & 0.1413 & Do not reject H0 \\
\hline
\end{tabular}




\begin{tabular}{|l|l|l|l|}
\hline Jaque-Bera test & Residuals are normal & 0.9575 & Do not reject H0 \\
\hline $\begin{array}{l}\text { Breusch-Godfrey } \\
\text { serial correlation LM } \\
\text { test }\end{array}$ & No serial correlation & 0.4953 & Do not reject H0 \\
\hline Ramsey RESET & $\begin{array}{l}\text { Model is correctly } \\
\text { specified }\end{array}$ & 0.3390 & Do not reject h0 \\
\hline CUSUM \& CUSUMSQ & At 5\% level of significance, the model is stable \\
\hline
\end{tabular}

Source: Own table based on results obtained from Eviews 9

In order to ensure accuracy of the model utilised, the study conducted diagnostics and stability tests. The heteroscedasticity test was carried out in order to test whether the variables were homoscedastic or heteroscedasticity. The Jacque-Bera normality test was carried out in order to test for normality, followed by the Breusch-Godfrey serial correlation test to test for autocorrelation among the variables. This was also followed by the Ramsey reset test to ensure that the model is correctly specified and the CUSUM and CUSUMSQ test to ensure that the model utilised is stable. From Table 5 above, the results reveal that the model passes all diagnostic and stability tests, where the findings showed that the series is homoscedastic, the residuals are normally distributed, there is no serial correlation and the model is stable, implying that the findings of this study are trustworthy.

\subsection{CONCLUSION AND RECOMMENDATIONS}

The highest spending category is attributed to basic education with a total expenditure of R262.4 billion (Budget Review, 2018). Be that as it may, the 2019/2020 budget indicates that R202.2 billion will be directed toward debt service costs. This translates to revenue that could have been directed towards other investment or profit-forming ventures that could have promoted economic growth and development in South Africa. However, as much as the government provides free basic education, there is a high demand for jobs as the country is characterised by high unemployment rates. If South Africa could direct their expenditure in such a way that the spill-over effects come back into the economy, this might improve economic growth. The results obtained by the study further suggest that the bailout of state-owned enterprises might have directed funds away from the people and into the SOEs, since the unemployment rate in South Africa continues to rise rapidly, indicating that more resources or expenditure need to be directed towards avenues that could potentially improve the economic conditions and reduce the current debt levels of South Africa. Taking into account the already strained budget and the continuous budget deficit, it is inevitable that the government will resort to borrowing. However, if government expenditure is financed through borrowing, and this expenditure fails to generate the required level of revenue for South Africa, this will mean that it will become very difficult for the South African government to repay its debts, which will ultimately affect economic growth. The study therefore suggests that government debt should be used for investment initiatives that should translate into economic growth that eventually enhances the well-being of people. The study further recommends that the South African government should formulate effective and efficient expenditure policies, as most spending is aimed toward non-profit activities as well as the misuse of funds by the government and its officials. The study also recommends more accountability and transparency with regard South Africa's revenue and spending. 


\section{REFERENCES}

Acemoglu, D. \& Robinson, J.A. 2008. Persistence of power, elites, and institutions. American Economic Review, 98(1):267-93.

Akitoby, B., Clements, B., Gupta, S. \& Inchauste, G. 2006. Public spending, voracity, and Wagner's law in developing countries. European Journal of Political Economy, 22(4):908-924.

Alesina, A. \& Tabellini, G. 2007. Bureaucrats or politicians? Part I: a single policy task. American Economic Review, 97(1):169-179.

Anderson, G.M. \& Tollison, R.D. 1986. Ricardo on the public debt: principle versus practice. Journal of the History of Economic Thought, 8(1):49-58.

Arpaia, A. \& Turrini, A. 2008. Government expenditure and economic growth in the EU: Long-run tendencies and short-term adjustment (Economic Papers 300). Brussels: Directorate-General for Economic and Financial Affairs.

Barro, R.J. 1974. Are government bonds net wealth? Journal of Political Economy, 82(6):1095-1117.

Barro, R.J. 1990. Government spending in a simple model of endogeneous growth. Journal of Political Economy, 98(5, Part 2):S103-S125.

Budget Review. 2018. National Treasury Republic of South Africa. file:///C:/Users/23722657/Desktop/ARDL\%20DEBT/2018\%20BUDGET\%20REVIEW.pdf. Date of access: 3 March 2018.

Budget Review. 2019. National treasury republic of South Africa. http://www.treasury.gov.za/documents/national\%20budget/2019/review/FullBR.pdf. Date of access: 12 August 2019.

Cameron, W. 2004. Public accountability: Effectiveness, equity, ethics. Australian Journal of Public Administration, 63(4):59-67.

Churchman, N. 2001. David Ricardo on public debt. Springer.

Dao, B. \& Doan, H. 2014. The relationship between budget deficit and economic growth in Vietnam-ARDL approach. https://papers.ssrn.com/sol3/papers.cfm?abstract_id=2514134. Date of access: 12 August 2019.

Devarajan, S., Swaroop, V. \& Zou, H. 1996. The composition of public expenditure and economic growth. Journal of Monetary Economics, 37(2):313-344.

Dube, S. \& Zhou, Y. 2013. The repo rate pass-through to the prime rate in South Africa: evidence from ARDL and FMLS models. Journal of Business Theory and Practice, 1(2):199-213.

Durham, J.B. 2004. Absorptive capacity and the effects of foreign direct investment and equity foreign portfolio investment on economic growth. European Economic Review, 48(2):285-306.

Eberhardt, M. \& Presbitero, A.F. 2015. Public debt and growth: Heterogeneity and non-linearity. Journal of International Economics, 97(1):45-58.

Goldsmith, A.A. 1995. The state, the market and economic development: A second look at Adam Smith in theory and practice. Development and Change, 26(4):633-650.

Habanabakize, T., Meyer, D.F. \& Muzindutsi, P.F. 2017. Econometric Analysis of the Effects of Aggregate Expenditure on Job Growth in the Private Sector: The South African Case. Acta Universitatis Danubius. OEconomica, 13(4). 
Islam, A.M. 2001. Wagner's law revisited: cointegration and exogeneity tests for the USA. Applied Economics Letters, 8(8):509-515.

International Monetary Fund. Research Dept. 2012. World economic outlook, October 2012: Coping with high debt and sluggish growth. Oxford University Press.

Jibao, S.S. 2013. Enhancing sustainable fiscal policy in South Africa (Doctoral dissertation, University of Pretoria).

Johansen, S. \& Juselius, K. 1990. Maximum likelihood estimation and inference on cointegration - with applications to the demand for money. Oxford Bulletin of Economics and Statistics, 52(2):169-210.

Kraay, A. \& Nehru, V. 2006. When is external debt sustainable?. The World Bank Economic Review, 20(3):341-365.

Kukeli, A. 2014. Revisiting the public debt-growth puzzle: evidence from Balkan countries. International Journal of Business \& Economics Perspectives, 9(1).

Lopes da Veiga, J., Ferreira-Lopes, A. \& Sequeira, T. 2014. Public debt, economic growth, and inflation in African economies.

Mamo, F.T. 2012. Economic growth and inflation: A panel data analysis. Sodertorn University, Master's thesis. http://www.diva-portal.org/smash/get/diva2:576024/FULLTEXT01.pdf. Date of access: 30 August 2019

Makin, A.J. 2015. Expansionary Versus Contractionary Government Spending. Contemporary Economic Policy, 33(1):56-65.

Masoga, M.M. 2018. The impact of public debt on economic growth in South Africa: a cointegration approach (Doctoral thesis, University of Limpopo).

Megersa, K. \& Cassimon, D. 2015. Public debt, economic growth, and public sector management in developing countries: Is there a link?. Public Administration and Development, 35(5):329-346.

Mellet, A. 2012. A critical analysis of South African economic policy (Doctoral thesis, North-West University).

Meniago, C., Mukuddem-Petersen, J., Petersen, M.A. \& Mongale, I.P. 2013. What causes household debt to increase in South Africa?. Economic Modelling, 33:482-492.

Modigliani, F., 1961. Long-run implications of alternative fiscal policies and the burden of the national debt. The Economic Journal, 71(284):730-755.

Mohr, P. \& Fourie, L. 2011. Economics for South African students. $4^{\text {th }}$ ed. Pretoria: Van Schaick Publishers.

Mupunga, N. \& Le Roux, P. 2016. Analysing the theoretical and empirical foundations of public debt dynamics in Zimbabwe. Studies in Economics and Econometrics, 40(1):95-118.

Nastansky, A., Mehnert, A. \& Strohe, H.G. 2014. A vector error correction model for the relationship between public debt and inflation in Germany.

Ncanywa, T. \& Masoga, M.M. 2018. Can public debt stimulate public investment and economic growth in South Africa?. Cogent Economics \& Finance, 6(1):1516483.

Nguyen, V.B. 2015. The relationship between public debt and inflation in developing countries: Empirical evidence based on difference panel GMM. Asian Journal of Empirical Research, 5(9):128-142.

Pegkas, P. 2018. The Effect of Government Debt and Other Determinants on Economic Growth: The Greek Experience. Economies 2018(6):10.

Pesaran, M.H. \& Shin, Y. 1996. Cointegration and speed of convergence to equilibrium. Journal of Econometrics, 71(1-2):117-143. 
Pesaran, M.H., Shin, Y. \& Smith, R.J. 2001. Bounds testing approaches to the analysis of level relationships. Journal of Applied Econometrics, 16(3):289-326.

Reinhart, C.M. \& Rogoff, K.S. 2010. Growth in a time of debt. American Economic Review, 100(2):573-78.

Statistics South Africa. 2018. GDP in the first quarter of 2018 contracted by $2.2 \%$. http://www.statssa.gov.za/?p=11209. Date accessed: 12 August 2019.

Stylianou, T. 2014. Debt and economic growth: Is there any causal effect? An empirical analysis with structural breaks and Granger causality for Greece. Theoretical and Applied Economics, 21(1):51-62.

Taghavi, M. 2001. Debt, growth and inflation in large European economies: a vector auto-regression analysis. In Capitalism and Democracy in the 21st Century (pp. 165-179). Physica, Heidelberg.

Thornton, J. 1999. Cointegration, causality and Wagner's Law in $19^{\text {th }}$ century Europe. Applied Economics Letters, 6(7):413-416.

Tsoulfidis, L. 2007. Classical economists and public debt. International Review of Economics, 54(1):1.

Wahab, M. 2004. Economic growth and government expenditure: evidence from a new test specification. Applied Economics, 36(19):2125-2135. 